\title{
Co nowego w leczeniu zaburzeń rytmu serca? Najnowsze doniesienia z Kongresu Asocjacji Zaburzeń Rytmu Europejskiego Towarzystwa Kardiologicznego (EHRA ESC) Wiedeń, 18-21 czerwca 2017
}

\author{
What is new in arrhythmia management? Congress report EUROPACE 2017? \\ Recent reports from the European Heart Rhythm Association \\ of the European Society of Cardiology (EHRA ESC) Congress \\ Vienna, June 18-21 2017
}

\author{
Michał Chudzik \\ Katedra i Klinika Kardiologii Uniwersytetu Medycznego w Łodzi
}

\begin{abstract}
Wstęp
Od 18 do 21 czerwca 2017 roku w Wiedniu odbywał się kolejny Kongres Asocjacji Zaburzeń Rytmu (EHRA, European Heart Rhythm) Europejskiego Towarzystwa Kardiologicznego (ESC, European Society of Cardiology), w czasie którego zaprezentowano kilka bardzo ciekawych wyników badań klinicznych mogących mieć istotne znaczeniu w leczeniu zaburzeń rytmu w praktyce lekarza ogólnego, rodzinnego czy kardiologa.
\end{abstract}

\section{Migotanie przedsionków}

Migotanie przedsionków (AF, atrial fibrillation) to bez wątpienia problem kliniczny spotykany się na co dzień zarówno na oddziałach klinicznych, ratunkowych czy w lecznictwie ambulatoryjnym. Obecnie, w celu profilaktyki zakrzepowo-zatorowej i obniżenia ryzyka udaru mózgu, bardzo dużo uwagi poświęca się dwóm problemom - wczesnej diagnostyce oraz wykrywaniu arytmii u chorych bez objawów klinicznych i/lub z nieznacznymi objawami. Temu problemowi był poświęcony rejestr GLORIA AF, do którego włączono aż 56 tys. chorych z 44 krajów. Celem tego badania była ocena kliniczna chorych z nowo wykrytym (do 3 mies.) AF. Aż 70\% chorych z nowo zdiagnozowanym AF stanowiły osoby bez żadnych objawów i/lub z minimalnymi objawami klinicznymi przed rozpoznaniem arytmii. Dane te ukazują, jak wielu chorych nie zgłosi się do lekarza z powodu objawowej arytmii serca i u jak wielu chorych nie zostanie wdrożone między innymi odpowiednie leczenie przeciwzakrzepowe. Konsekwencją kliniczną tych danych w rejestrze GLORIA AF był fakt, że w tej grupie pacjentów 2-krotnie częściej pierwszym objawem AF był udar mózgu (14,7\% chorych bez i/lub z minimalnymi objawami klinicznymi v. $6 \%$ u chorych z objawowym AF). Jeden z wniosków z tego rejestru był taki, że istnieje bezwzględna potrzeba wczesnej diagnostyki bezobjawowych AF.

Drugim interesującym badaniem dotyczącym AF, zaprezentowanym przez zespół norweski, był screening chorych po 65. roku życia (ACE 1950 STUDY) w celu okreśIenia częstości występowania bezobjawowych AF. Chorzy bez wywiadu arytmii serca z punktacją ponad 2 w skali $\mathrm{CHA}_{2} \mathrm{DS}_{2}$-VASc byli monitorowani elektrokardiograficznie (EKG) przez 2 tygodnie. W tak krótkim okresie obserwacji AF zarejestrowano aż u 0,9\%, u który do tej pory nigdy nie rozpoznano tego schorzenia. W analizie wieloczynnikowej do głównych czynników ryzyka AF należały nadciśnienie tętnicze i cukrzyca.

Te dwa doniesienia zaprezentowane w czasie Kongresu EUROPACE 2017 jednoznacznie wskazują potrzebę zinten- 
syfikowania wczesnej ambulatoryjnej diagnostyki AF. Wydaje się, że w bardzo krótkim czasie standardem screeningu detekcji arytmii będą aplikacje w urządzeniach mobilnych. Badacze z Wielkiej Brytanii porównali dwie dostępne obecne aplikacje na smartfony, tj. Beat Scanner i Preventicus. Oba oprogramowania uzyskują bardzo wysoką czułość w detekcji AF: Beat Scanner - 89\%, Preventicus - 94\%. Ten drugi system zdobył aż 2-krotnie lepszą pozytywną opinię użytkowników, jako prostszy i bardziej przyjazny. Zapewne technologia ta w bardzo krótkim czasie stanie się standardem we wczesnej detekcji arytmii, co pozwoli istotnie obniżyć obecnie bardzo wysoki odsetek udarów mózgu jako pierwszy objaw AF.

Jaki lek antyarytmiczny wybrać u chorych po ablacji żył płucnych (PVI, pulmonary vein isolation)? Na to pytanie próbowano odpowiedzieć w badaniu przeprowadzonym przez lekarzy w Stanach Zjednoczonych i Rosji. Włączonego do niego 243 pacjentów, których zależnie od terapii antyarytmicznej podzielono na grupy: I - przyjmująca werapamil, II - przyjmującą propafenon, III - przyjmującą sotalol, IV - bez leków antyarytmicznych. W czasie trwającej rok obserwacji średnia skuteczność PVI wynosiła $67 \%$ w przypadku pierwszej ablacji i aż $89 \%$ w przypadku 2-krotnej PVI, i nie wpłynęło na nią leczenie antyarytmiczne . Najskuteczniejszym lekiem, istotnie zmniejszającym częstość kardiowersji elektrycznej, farmakologicznej oraz hospitalizacji z powodu AF, okazał propafenon.

\section{Terapia resynchronizująca serca}

Terapia resynchronizująca serca (CRT, cardiac resynchronization therapy) jest uznaną metodą terapii niewydolności serca. W dalszym ciągu próbuje się jednak znaleźć przyczynę faktu, aż 30-40\% chorych poddawanych terapii tą metodą nie odnosi spodziewanych z niej korzyści. Bez wątpienia jedną z przyczyn jest odpowiednia kwalifikacji chorych. Chorzy z obrazem lewej odnogi pęczka Hisa (LBBB, left bundle branch block), z czasem trwania QRS powyżej 150 ms w zapisie EKG, są najlepszymi kandydatami do implantacji CRT. Temu tematowi poświęcono kilka badań w czasie Kongresu EUROPACE. Wydaje się, że dla codziennej praktyki największe znaczenie mogą mieć wyniki przedstawione przez Jana de Pootera z Belgii, które wykazały, że wyłącznie na podstawie automatycznego pomiaru QRS w zapisie EKG aż 33\% chorych może nie zostać kwalifikowanych do zabiegu CRT z powodu błędu pomiaru. Do czasu ulepszenia obecnych algorytmów w aparatach EKG zaleca się ręczny pomiar czasu trwania zespołu QRS u pacjentów z LBBB kwalifikowanych do zabiegu CRT. 